\title{
Zróżnicowanie i zmiany rzeźby terenu historycznego pola górniczego na Osicowej Górze k. Stąporkowa (NW obrzeżenie Gór Świętokrzyskich)
}

\author{
Piotr Kusztal $^{1}$, Grzegorz Pabian ${ }^{1}$, Tomasz Kalicki ${ }^{1}$, Ewa Nowak ${ }^{1}$, Paweł Przepióra $^{1}$
}

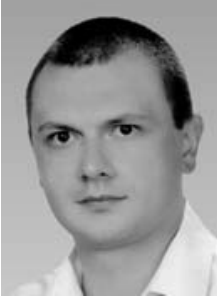

P. Kusztal

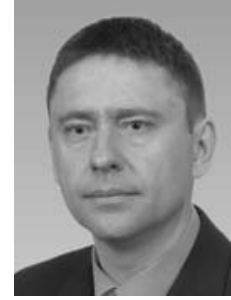

G. Pabian

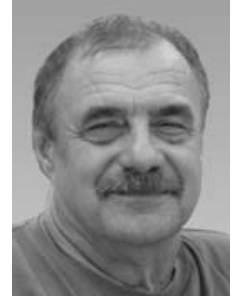

T. Kalicki

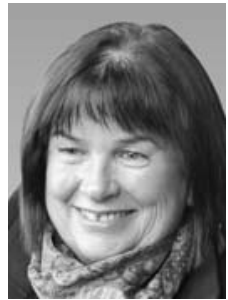

E. Nowak

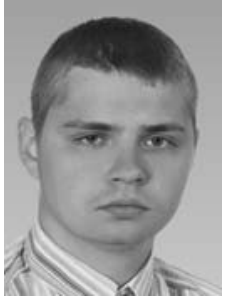

P. Przepióra

Differentiation and changes of the relief of historical mining field of the Osicowa Góra hill near Stąporków (NW margin of the Holy Cross Mountains). Prz. Geol., 68: 127-134; doi: 10.7306/2020.5

A b s $\operatorname{tr}$ a c t. As a result of historical human interference in the natural environment (iron ore mining) of the Osicowa Góra hill area, there are very clear relief transformations, whose location reflects the occurrence of minerals (the geological structure). Geomorphological forms, co-creating the post-industrial relief, are of various sizes, concentrations, arrangements and ages. They are susceptible to the impact of exogenous processes. Their secondary transformations are highly dynamic.

Keywords: geomorphology, historical iron ore mining, the Osicowa Góra hill

Ingerencja człowieka w środowisko naturalne przybiera różne formy i natężenie. Górnictwo jest dziedziną antropopresji, która prowadzi do wyraźnych i trwałych zmian rzeźby terenu (por. Radwanek-Bąk, 2001; Kaszowska, 2007), a więc kształtuje krajobraz kulturowy (por. Myga-Piątek, 2012). Obszary eksploatacji cechują się zazwyczaj swoistym, antropogenicznym ukształtowaniem powierzchni terenu (por. np. Król, Urban, 2003), warunkującym różne procesy, m.in. hydrologiczne i geomorfologiczne. Ostatnio tereny te coraz częściej są obiektem badań (por. m.in. Kaptur, 2014; Sztampke, 2014; Rutkiewicz, Gawior, 2015; Maciejak i in., 2017; Rutkiewicz, 2017; Kalicki i in., 2018; Pabian, Kusztal, 2019; Pabian i in., 2019; Przepióra i in., 2019). Podkreślane są także ich walory turystyczne (Borzęcki, Marek, 2016; Młodawski, 2017).

W NW części obrzeżenia mezozoicznego Gór Świętokrzyskich krajobrazem poeksploatacyjnym charakteryzują się tereny należące niegdyś do Staropolskiego Okręgu Przemysłowego (SOP). W okręgu tym przez kilka stuleci eksploatowano rudy żelaza, wykorzystywane przez przemysł metalurgiczny (Chłopek, 2017; Nowak, 2017). Początki tej działalności sięgają czasów późnego średniowiecza (Kubicki, Saletra, 2013; Nowak, 2017), natomiast koniec jest datowany na przełom lat 60. i 70. XX w., kiedy zamknięto ostatnie kopalnie (Chłopek, 2017).

W niniejszym artykule przedstawiono morfologię górniczego pola Osicowa Góra k. Stąporkowa, użytkowanego w czasach SOP, w obrębie którego stwierdzono szczególnie duże przeobrażenia krajobrazu, rzutujące na funkcjonowanie geoekosystemu. Celem badań było rozpoznanie przyczyn zróżnicowania rzeźby terenu tego pola, a także przedstawienie niektórych przyrodniczych konsekwencji (głównie geomorfologicznych) historycznej eksploatacji rud żelaza w jego granicach.

\section{OBSZAR BADAN}

Badania prowadzono na wierzchowinie obejmującej Osicową Górę, wznoszącą się na wysokość 334,2 m n.p.m. (ryc. 1), i bezimienne wzgórze usytuowane na wschód od niej (Wielomska, 2000). Obszar ten leży w międzyrzeczu Czarnej Koneckiej i Krasnej w zlewni Pilicy (dorzecze Wisły), a pod względem administracyjnym należy do gminy Stąporków w powiecie koneckim (woj. świętokrzyskie). Według regionalizacji fizycznogeograficznej Solona i in. (2018) znajduje się na Wyżynie Kieleckiej, na pograniczu Płaskowyżu Suchedniowskiego i Garbu Gielniowskiego, natomiast w podziale geomorfologicznym Gilewskiej (1972) należy do Wzgórz Koneckich.

Szczytowe partie Osicowej Góry tworzą dolnojurajskie piaskowce, mułowce i iłowce (hetang-synemur) z wkładkami syderytów ilastych (Mizerja, 1947; Filonowicz, 1981; Złonkiewicz, 2019), wśród których występuje przysuska formacja rudonośna (por. Pieńkowski, 2004; Fijałkowska-Mader, Złonkiewicz, 2019), zwana przez Krajewskiego (1955) serią rudną (łupki z flora, iły, rudy żelaza i piaskowce). Formacja ta zawiera 3 horyzonty rudonośne, tj. poziom trzeci rudy wiśniowej, poziom drugi rudy perłowej i najpłytszy poziom pierwszy (Mizerja, 1947; Krajewski, 1955), którego wychodnie z trzech stron $(\mathrm{N}, \mathrm{E}, \mathrm{S})$ otaczają pole górnicze na Osicowej Górze (ryc. 2).

Utwory rudonośne należą do płaskiej synkliny (Mizerja, 1947), której oś (WNW-ESE) znajduje się w środkowej

\footnotetext{
${ }^{1}$ Instytut Geografii i Nauk o Środowisku, Uniwersytet Jana Kochanowskiego w Kielcach, ul. Uniwersytecka 7, 25-406 Kielce; roch1990@gmail.com; g.pabian@wp.pl, tomaszkalicki@ymail.com; ewa.nowak@ujk.edu.pl; pawelprzepiora1988@gmail.com
} 


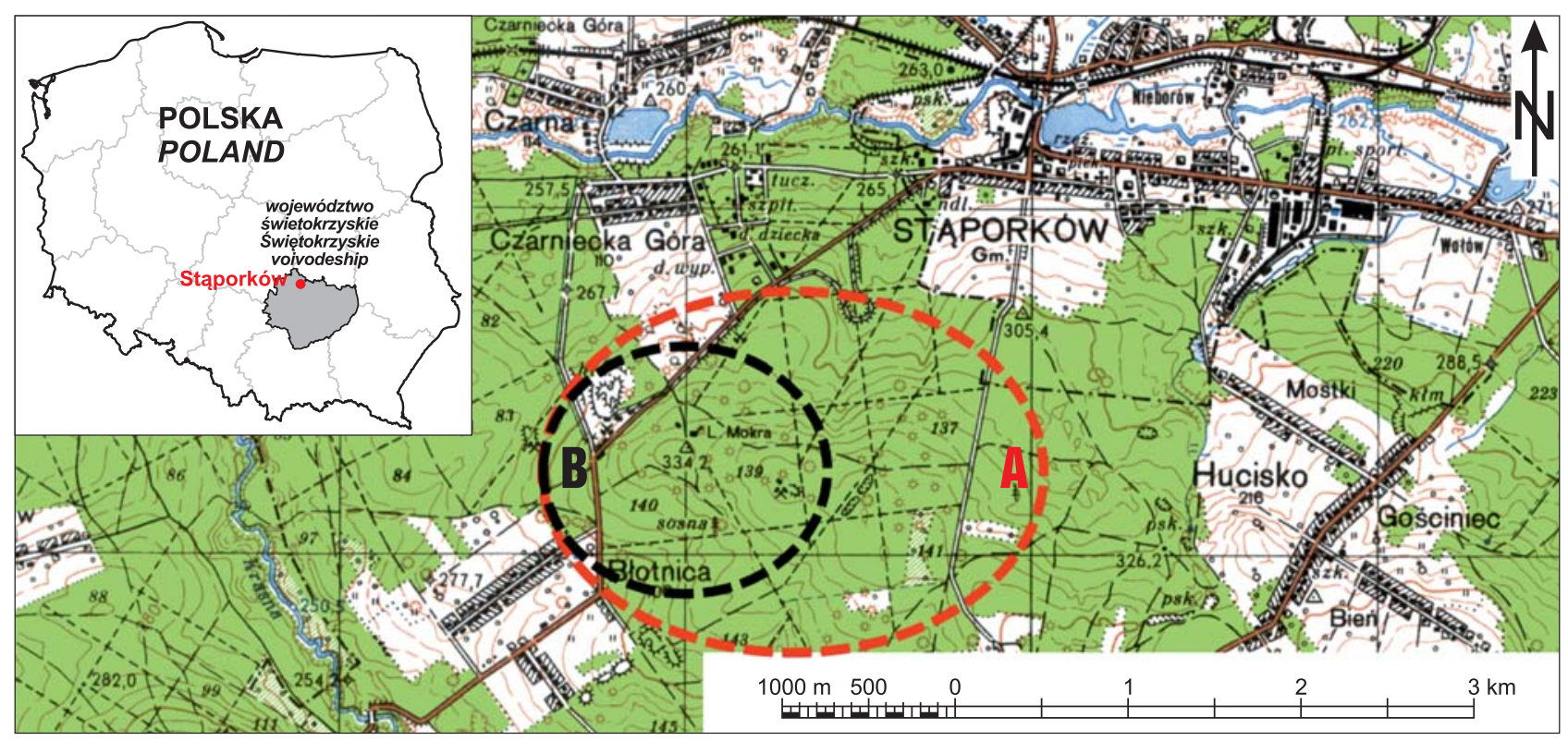

Ryc. 1. Lokalizacja historycznych pól górniczych: A - na SW od Stąporkowa; B - w rejonie Osicowej Góry (Wielomska, 2000)

Fig. 1. Location of historical mining fields: A-to SW from Stąporków; B - in the area of the Osicowa Góra hill (Wielomska, 2000)

części badanego terenu. W jądrze tej synkliny na utworach serii rudnej zalegają piaskowce, łupki ilaste i iły serii szydłowieckiej (Krajewski, 1955), tj. formacji ostrowieckiej (Pieńkowski, 2004, Fijałkowska-Mader, Złonkiewicz, 2019; Złonkiewicz, 2019). Około 200 m na północny wschód od pola górniczego synklinę przecina uskok o przebiegu NW-SE (Mizerja, 1947).

W czasach historycznych na wierzchowinie Osicowej Góry prowadzono podziemną eksploatację wielopokładowego złoża syderytów (Mizerja, 1947). Pozostałością po tej działalności jest pole górnicze o powierzchni ok. 80 ha (ryc. 2) z ponad 300 szybikami i towarzyszącymi im usypiskami (ryc. 3), a także z dwoma zwałowiskami skały płonnej. Najstarsze usypiska są datowane na średniowiecze (Nowak, 2017). Ostatnia kopalnia Edward, po której pozostało zwałowisko północno-zachodnie (ryc. 4), była czynna przez ok. 20 lat i przestała funkcjonować na przełomie lat 60. i 70. ubiegłego stulecia (Kuliński, 2014).

W XX w. na skutek działalności górniczej w promieniu kilku kilometrów od kopalni Edward powstał lej depresyj-

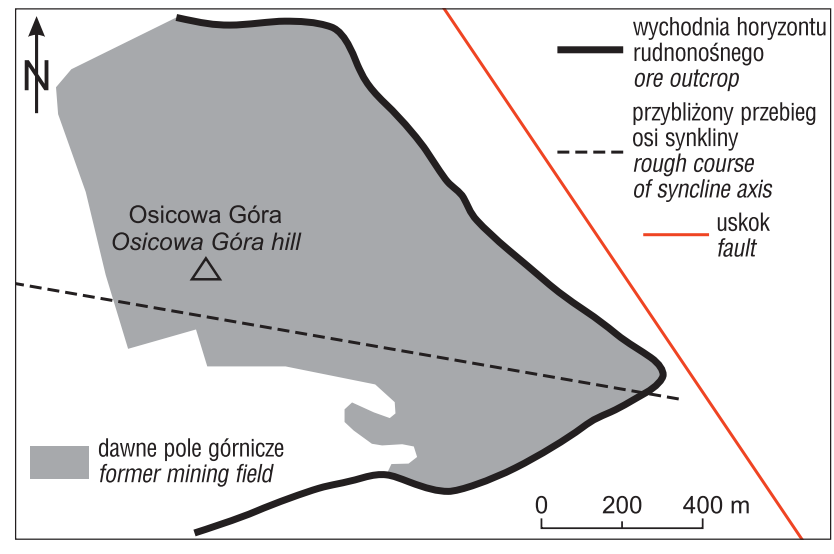

Ryc. 2. Szkic sytuacyjny obszaru badań z wybranymi elementami geologii (Mizerja, 1947, uproszczony)

Fig. 2. Situational sketch of the study area with selected elements of geology (Mizerja, 1947, simplified)

ny. Konsekwencją tego było wyschnięcie studni w pobliskich miejscowościach oraz zanik źródełka w Czarnieckiej

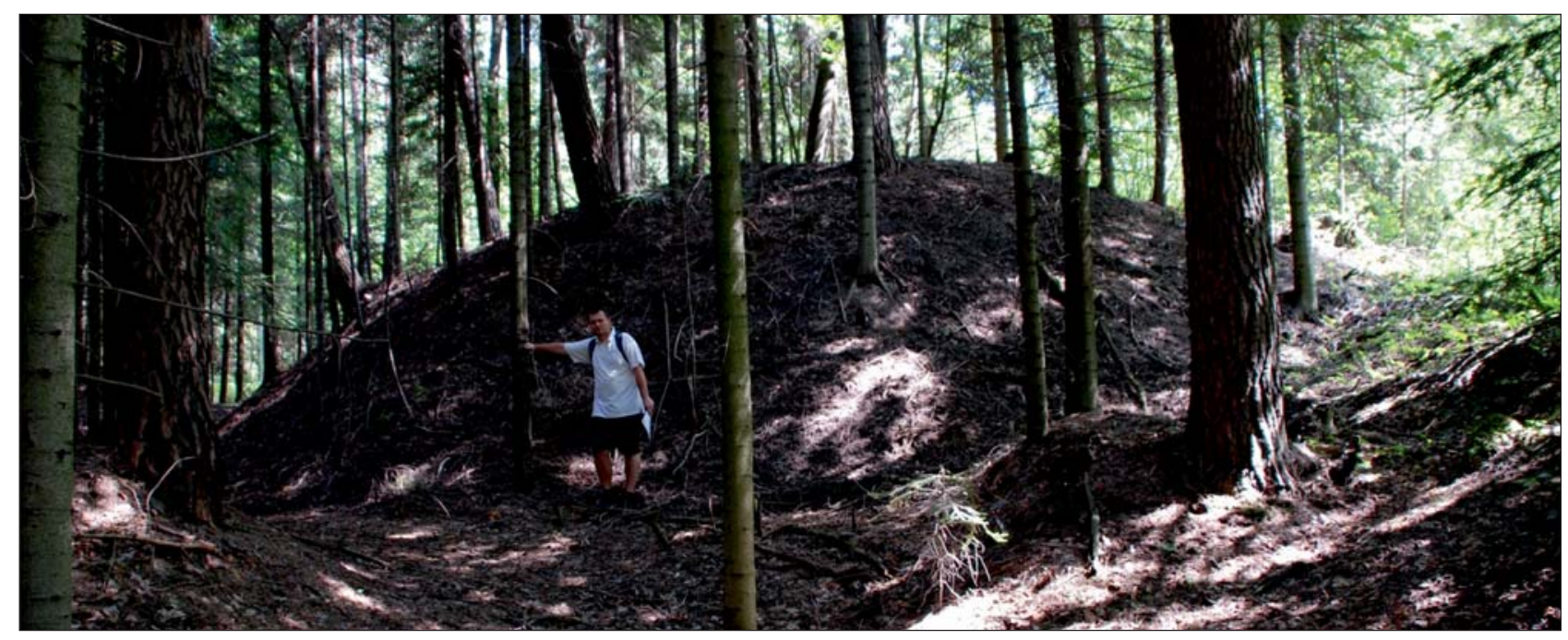

Ryc. 3. Usypisko skały płonnej (warpa) na Osicowej Górze. Fot. G. Pabian, 2019

Fig. 3. The gangue mound of the Osicowa Góra hill. Photo by G. Pabian, 2019 


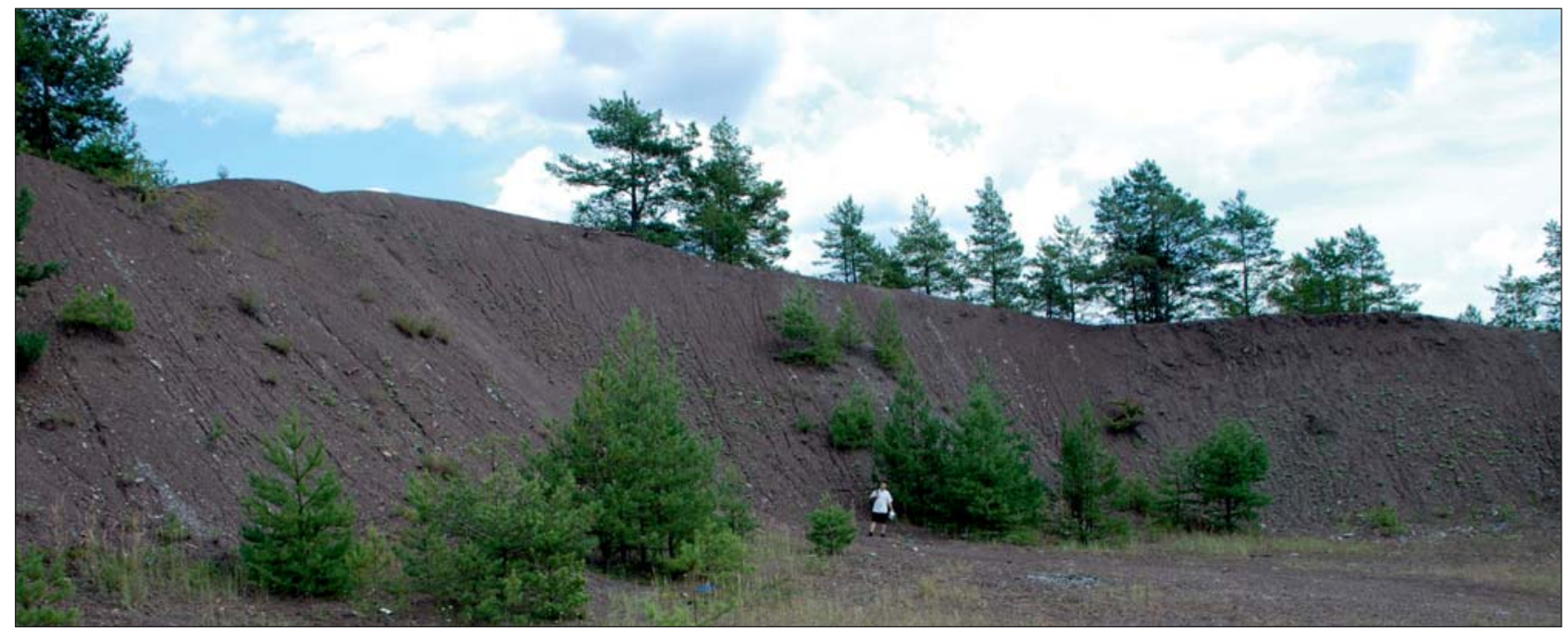

Ryc. 4. Zwałowisko z XX w. na Osicowej Górze. Fot. G. Pabian, 2019

Fig. 4. The mining heap from the $20^{\text {th }}$ century on the Osicowa Góra hill. Photo by G. Pabian, 2019



Ryc. 5. Numeryczny model terenu pola górniczego na Osicowej Górze k. Saporkowa (mapy.geoportal.gov.pl) z zaznaczonymi analizowanymi zbiorami form rzeźby terenu: 1 - zbiór warp średniowiecznych (lub też późniejszych, a także rowów i szybów poszukiwawczych), 2 i 3 - zbiory starszych warp nowożytnych (lub z ostatnich dwóch stuleci), $\mathbf{4}$-zbiór młodszych warp nowożytnych (lub $\mathrm{z}$ ostatnich dwóch stuleci), 5 - zwałowisko (XX w.)

Fig. 5. The relief of the mining field in the Osicowa Góra area on the DEM (mapy.geoportal.gov.pl) and analyzed sets of forms: 1 -a set of medieval (or/and later) forms or/and exploration ditches/shafts, $\mathbf{2}$ and $\mathbf{3}$ - sets of older modern forms or/and from the last two centuries, $\mathbf{4}$ - a set of younger modern forms or/and from the last two centuries, $\mathbf{5}$ - mining heap ( $20^{\text {th }}$ century)

Górze (Kuliński, 2014), które było symbolem uzdrowiska rozwijającego się tu do wybuchu II wojny światowej (Werens, 2005). W okresie funkcjonowania kopalni notowano także tąpnięcia spowodowane drążeniem chodników przy użyciu materiałów wybuchowych (Kuliński, 2014; Nowak, 2017). Od zakończenia eksploatacji postępuje renaturalizacja obszaru z wtórną sukcesją roślinności (ok. pół wieku). 


\section{METODYKA}

W 2019 r. przeprowadzono obserwacje terenowe pola górniczego na Osicowej Górze, w ramach których udokumentowano występujące na nim antropogeniczne formy rzeźby terenu oraz skutki współczesnych procesów morfodynamicznych. Do dalszych analiz wybrano niektóre formy poeksploatacyjne, m.in. największe zwałowisko oraz odsypy skały płonnej w rejonie szybików wydobywczych, czyli tzw. warpy. Formy te zidentyfikowano na numerycznym modelu terenu (NMT), udostępnionym przez serwis mapy.geoportal.gov.pl. Na modelu tym pomierzono powierzchnię usypisk, ich wysokość względna, a także odległości pomiędzy kopczykami. Następnie na badanym polu górniczym wyznaczono cztery obszary charakteryzujące się występowaniem podobnych usypisk skały płonnej (tj. warp o zbliżonych cechach morfologicznych, wielkości i rozmieszczeniu), a zwałowisko uznano za piąty analizowany obszar (ryc. 5). Powierzchnia tych pięciu obszarów (zbiorów) i liczba znajdujących się na nich usypisk (obiektów) są przypadkowe. Ten subiektywny podział na zbiory zweryfikowano za pomocą samouczącej się sieci neuronowej (Kohonen, 1997; Nowak, 2004), która również pogrupowała warpy i zwałowisko na zasadzie podobieństw, ale na podstawie wyników pomiarów trzech cech morfologicznych, wprowadzonych do oprogramowania Statistica, takich jak, powierzchnia i wysokość tych form oraz odległości między nimi (tab. 1). Korzystając z danych

Tab. 1. Cechy morfologiczne (zmienne) antropogenicznych form terenu subiektywnie przydzielonych do 5 zbiorów, użyte do klasyfikacji tych form metodą sztucznych sieci neuronowych Kohonena: A - powierzchnia [m²], B - wysokość względna [m], $\mathbf{C}-$ odległość do najbliższego usypiska [m]

Table 1. Morphological features (variables) of anthropogenic forms in subjectively designated 5 sets, used in the classification made with a Kohonen's artificial neural networks: $\mathbf{A}$ - surface area $\left[\mathrm{m}^{2}\right], \mathbf{B}$ - relative height $[\mathrm{m}], \mathbf{C}$ - distance to the nearest gangue mound $[\mathrm{m}]$

\begin{tabular}{|c|c|c|c|c|c|c|c|c|c|c|c|c|c|}
\hline \multicolumn{3}{|c|}{$\begin{array}{c}\text { Zbiór } 1 \\
\text { Set } 1\end{array}$} & \multicolumn{3}{|c|}{$\begin{array}{c}\text { Zbiór } 2 \\
\text { Set } 2 \\
\end{array}$} & \multicolumn{3}{|c|}{$\begin{array}{c}\text { Zbiór } 3 \\
\text { Set } 3\end{array}$} & \multicolumn{3}{|c|}{$\begin{array}{c}\text { Zbiór } 4 \\
\text { Set } 4\end{array}$} & \multicolumn{2}{|c|}{$\begin{array}{c}\text { Zbiór } 5 \\
\text { Set } 5\end{array}$} \\
\hline $\mathbf{A}$ & B & C & $\mathbf{A}$ & B & C & $\mathbf{A}$ & B & C & $\mathbf{A}$ & B & C & A & B \\
\hline 169,5 & 0,3 & 0 & 106,9 & 0,9 & 8,1 & 314,6 & 1,7 & 15,5 & 390,9 & 2,1 & 26,8 & 40000 & 34,4 \\
\hline 291,9 & 0,2 & 0 & 348,2 & 1,1 & 14 & 368,7 & 1,9 & 21,2 & 469,2 & 3,3 & 29,6 & - & - \\
\hline 233,1 & 0,6 & 0 & 662,2 & 0,9 & 0 & 385,1 & 1,6 & 11,1 & 490,1 & 1,7 & 34,5 & - & - \\
\hline 276,5 & 0,5 & 0 & 593,5 & 1,5 & 6,8 & 317,1 & 1,5 & 25 & 453,7 & 1,6 & 26,5 & - & - \\
\hline 330,7 & 1,5 & 0 & 314 & 2,1 & 8,8 & 293,5 & 1,7 & 8,2 & 372,7 & 3 & 27,9 & - & - \\
\hline 201,7 & 1,6 & 0 & 255,1 & 0,8 & 12,6 & 321 & 1,9 & 36,1 & 510 & 3,2 & 30,7 & - & - \\
\hline 174,5 & 0,8 & 0 & 726,2 & 1,2 & 2,5 & 278,9 & 0,9 & 0,5 & 557,2 & 2,2 & 33,6 & - & - \\
\hline 160 & 0,1 & 0 & 493,8 & 1,6 & 9,5 & 331,2 & 1,3 & 18,2 & 501,6 & 2,8 & 28,1 & - & - \\
\hline 148,4 & 0,5 & 0 & 530,2 & 1 & 3,6 & 345,4 & 1,2 & 0 & 480,7 & 2,9 & 27 & - & - \\
\hline 127,5 & 0,9 & 0 & 618,9 & 2 & 7,8 & 350,5 & 1,4 & 25,3 & 414,9 & 3,4 & 23,1 & - & - \\
\hline 79,1 & 0,5 & 0 & 616,6 & 1 & 1,8 & 246,3 & 1,6 & 4,6 & 420,7 & 2,8 & 26,7 & - & - \\
\hline 146,9 & 0,4 & 0 & 247,8 & 1,6 & 2,4 & 249,5 & 1,3 & 2,6 & 392,3 & 1,1 & 31,6 & - & - \\
\hline 143,7 & 1,3 & 0 & 265,2 & 1,1 & 2,1 & 236,6 & 2,3 & 24,6 & 503 & 2,6 & 31 & - & - \\
\hline- & - & - & 232,6 & 1,5 & 1,4 & 354,5 & 1,9 & 4,3 & 560,8 & 2,6 & 37,6 & - & - \\
\hline- & - & - & 466,6 & 1,3 & 2,5 & 304,9 & 1,2 & 16,2 & 488,2 & 3,4 & 25,8 & - & - \\
\hline- & - & - & 755,4 & 1,5 & 6,5 & 271,2 & 1 & 24,7 & 567,4 & 3,8 & 34 & - & - \\
\hline- & - & - & 676,8 & 1,4 & 3,5 & 165,7 & 0,3 & 15,9 & 472,4 & 3,4 & 35,3 & - & - \\
\hline- & - & - & 266,4 & 2,1 & 2,4 & 137,7 & 1,5 & 37,3 & 438,5 & 3,1 & 31,4 & - & - \\
\hline- & - & - & 378,8 & 2 & 10,7 & 324,8 & 1,2 & 8,4 & 274,6 & 1,9 & 25,8 & - & - \\
\hline- & - & - & 137,8 & 1,2 & 8,1 & 270,6 & 1,4 & 5,9 & 393,3 & 2,2 & 27,5 & - & - \\
\hline- & - & - & 477,9 & 0,9 & 4 & 224,1 & 2 & 15,7 & 513 & 2,8 & 18,4 & - & - \\
\hline- & - & - & 418,8 & 1,5 & 15,2 & 198 & 1,3 & 0,5 & 430,6 & 3 & 24,8 & - & - \\
\hline- & - & - & 460,3 & 0,8 & 0 & 297 & 1,7 & 18,4 & - & - & - & - & - \\
\hline- & - & - & 603,8 & 1 & 14,7 & 295,6 & 1,2 & 0,5 & - & - & - & - & - \\
\hline- & - & - & 549,5 & 1,8 & 4 & 314 & 1,1 & 17,5 & - & - & - & - & - \\
\hline- & - & - & 283,5 & 1,2 & 0 & 327 & 1,5 & 0,5 & - & - & - & - & - \\
\hline- & - & - & 251,7 & 1,2 & 2,7 & 305,5 & 1,2 & 13,1 & - & - & - & - & - \\
\hline- & - & - & 254,3 & 1,1 & 1,5 & 283,6 & 1,9 & 0 & - & - & - & - & - \\
\hline- & - & - & 515,8 & 1 & 3,9 & 267,7 & 2,4 & 17,8 & - & - & - & - & - \\
\hline- & - & - & 636,4 & 1,9 & 11 & 413,7 & 2 & 2,9 & - & - & - & - & - \\
\hline- & - & - & 409,2 & 1,3 & 12,1 & 437,4 & 1,8 & 17 & - & - & - & - & - \\
\hline- & - & - & 350,8 & 0,9 & 5,9 & 391,7 & 2,2 & 18,9 & - & - & - & - & - \\
\hline
\end{tabular}


literaturowych (Mizerja, 1947; Bednarski, 1955; Krajewski, 1955; Król, Urban, 2003; Kuliński, 2014; Rutkiewicz, Gawior, 2015; Chłopek, 2017; Nowak, 2017; Rutkiewicz, 2017) wydzielonym pięciu zbiorom form przypisano hipotetyczny czas eksploatacji złoża. W ten sposób ustalono szacunkowy wiek form pogórniczych, odpowiadający ich różnemu układowi, parametrom i stopniowi zachowania $\mathrm{w}$ krajobrazie.

\section{WYNIKI}

$\mathrm{Na}$ polu górniczym usytuowanym na wierzchowinie Osicowej Góry udokumentowano liczne formy antropogeniczne, takie jak zrównania terenu, wyrobiska (szyby), wcięcia i nasypy drogowe, odsypy (warpy) i zwałowiska skały płonnej, tworzące swoisty poprzemysłowy krajobraz kulturowy, cechujący się urozmaiconą rzeźbą terenu (ryc. 3-5). Antropogeniczne formy terenu wyróżnione na tym polu różnią się pod względem rozmiarów i rozmieszczenia (ryc. 5, tab. 1, 2). Zmienność tę można wiązać z różnymi fazami eksploatacji złoża, odznaczającymi się inną technologią wydobywania rudy (por. Chłopek, 2017), innym przeznaczeniem szybów (por. Rutkiewicz, 2017), a także czasem ich użytkowania oraz oddziaływania procesów denudacyjnych. Rozmieszczenie i rozmiary tych form mogą być także uzależnione od budowy geologicznej (por. Rutkiewicz, Gawior, 2015) oraz rzeźby terenu.

Wyniki klasyfikacji badanych form z wykorzystaniem samouczącej się sieci neuronowej wskazują, że subiektywnie wyznaczone zbiory form $(1,4,5$; ryc. 5) różnią się istotnie między sobą pod względem analizowanych cech, tj. wartości zmiennych (tab. 1). Na tzw. mapie Kohonena zbiory te zostały wydzielone jako trzy odrębne klastry (ryc. 6). Obiekty ze zbiorów drugiego i trzeciego są skupione w dwóch klastrach, przy czym jeden z nich jest rozległy i obejmuje obiekty z obu zbiorów. Z jednej strony świadczy to

Tab. 2. Parametry i cechy form antropogenicznych w wyznaczonych zbiorach 1-5

Table 2. Parameters and features of anthropogenic forms in designated sets $1-5$

\begin{tabular}{|c|c|c|c|c|c|c|}
\hline \multirow{3}{*}{$\begin{array}{l}\text { Forma } \\
\text { Form }\end{array}$} & \multirow{2}{*}{$\begin{array}{l}\text { Parametr lub cecha } \\
\text { Parameter of feature }\end{array}$} & \multicolumn{5}{|c|}{ Zbiory / Sets } \\
\hline & & 1 & 2 & 3 & 4 & 5 \\
\hline & $\begin{array}{l}\text { Powierzchnia obszaru [ha] } \\
\text { Surface area [ha] }\end{array}$ & 1,1 & 2,9 & 3,6 & 4,8 & 4,8 \\
\hline \multirow{2}{*}{$\begin{array}{l}\text { Zwałowisko } \\
\text { Heap }\end{array}$} & $\begin{array}{l}\text { Powierzchnia [ha] } \\
\text { Area [ha] }\end{array}$ & - & - & - & - & 4,0 \\
\hline & $\begin{array}{l}\text { Wysokość względna [m] } \\
\text { Relative height [m] }\end{array}$ & - & - & - & - & 34,4 \\
\hline \multirow{4}{*}{$\begin{array}{l}\text { Warpy } \\
\text { Gangue mounds }\end{array}$} & $\begin{array}{l}\text { Śr. powierzchnia }\left[\mathrm{m}^{2}\right] \\
\text { Average surface area }\left[\mathrm{m}^{2}\right]\end{array}$ & 191 & 435 & 301 & 459 & - \\
\hline & $\begin{array}{l}\text { Śr. wysokość względna }[\mathrm{m}] \\
\text { Average relative height }[\mathrm{m}]\end{array}$ & 0,7 & 1,3 & 1,5 & 2,7 & - \\
\hline & $\begin{array}{l}\text { Koncentracja } \\
\text { Concentration }\end{array}$ & $\begin{array}{c}\text { b. duża } \\
\text { very high }\end{array}$ & $\begin{array}{l}\text { duża } \\
\text { high }\end{array}$ & $\begin{array}{l}\text { średnia } \\
\text { medium }\end{array}$ & $\begin{array}{l}\text { mała } \\
\text { low }\end{array}$ & - \\
\hline & $\begin{array}{l}\text { Układ } \\
\text { Arrangement }\end{array}$ & $\begin{array}{l}\text { chaotyczny } \\
\text { chaotic }\end{array}$ & $\begin{array}{l}\text { chaotyczny } \\
\text { chaotic }\end{array}$ & $\begin{array}{l}\text { chaotyczny } \\
\text { chaotic }\end{array}$ & $\begin{array}{l}\text { regularny } \\
\text { regular }\end{array}$ & - \\
\hline
\end{tabular}

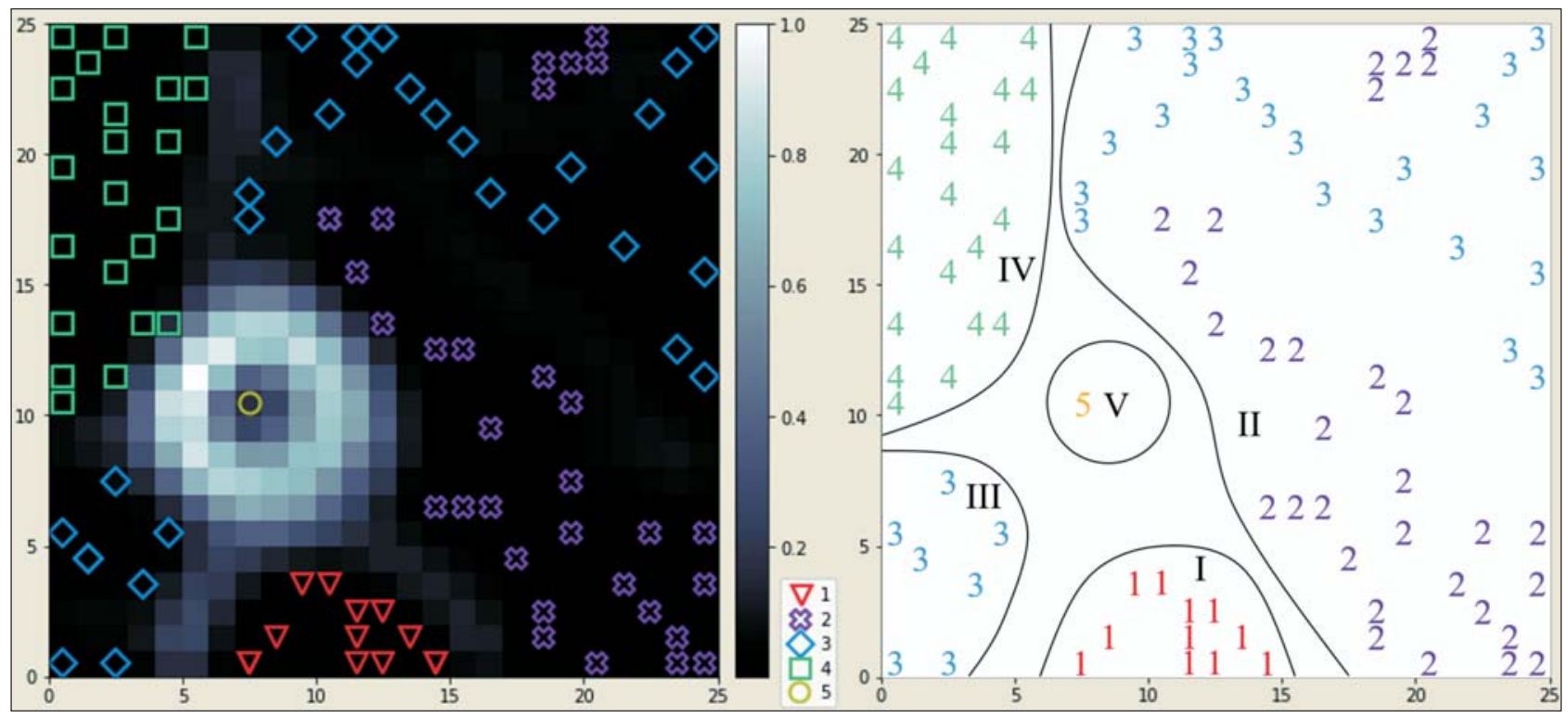

Ryc. 6. Klasyfikacja form antropogenicznych metodą sztucznych sieci neuronowych Kohonena (oprac. E. Nowak w oprogramowaniu Statistica i Python): 1-5 - analizowane zbiory, I-V - wygenerowane klastry (skupienia)

Fig. 6. Classification of anthropogenic forms by the method of Kohonen's artificial neural networks - self-organizing map (by E. Nowak in Statistica and Python): 1-5 - analyzed sets, I-V - generated clusters 
o wzajemnym podobieństwie tych zbiorów (ich niektórych obiektów), a z drugiej o ich wewnętrznym zróżnicowaniu w każdym z obszarów występują formy, których wymiary istotnie odbiegają od średnich wartości analizowanych cech.

Budowa geologiczna i współczesna rzeźba badanego terenu wpływają na obieg materii i stosunki wodne. Złoże na znacznym obszarze jest przykryte średnio przepuszczalnymi utworami formacji ostrowieckiej (Soja, 2003; Złonkiewicz, 2019) oraz pokrywą zwięzłej skały płonnej. Grunt jest więc uszczelniony, co spowalnia infiltrację i warunkuje większy spływ powierzchniowy. W jego wyniku powstają bruzdy erozyjne, szczególnie we wcięciach drogowych oraz na formach rzeźby o znacznych deniwelacjach i rzadszej pokrywie roślinnej. Najliczniej występują one na skarpach zwałowiska (ryc. 7A), rzadziej warp, natomiast najgłębsze są notowane na niektórych odcinkach pogórniczej sieci komunikacyjnej, zwłaszcza poboczach dróg (ryc. 7B-C). Do największych przeobrażeń dochodzi podczas nawalnych opadów deszczu, w trakcie których często powstają nowe systemy żłobin, a także następuje przemieszczanie materiału mineralnego w starych bruzdach oraz ich pogłębianie.

Procesy stokowe (ruchy masowe oraz spłukiwanie) zachodzące w obrębie wlotów do poszczególnych wyrobisk (szybów), prowadzą do zapełniania ich osadami, a w konsekwencji do ich zaczopowania (ryc. 8), czemu często sprzyja składowanie w nich odpadów komunalnych (puszek, butelek, torebek foliowych itp.). W zaczopowanych szybach powstają okresowe i epizodyczne zbiorniki retencyjne wód opadowych (Sztampke, 2014; Rutkiewicz, 2017), a drożne szyby stanowią drogę punktowego zasilania wód podziemnych z pominięciem infiltracji w strefie przypowierzchniowej.

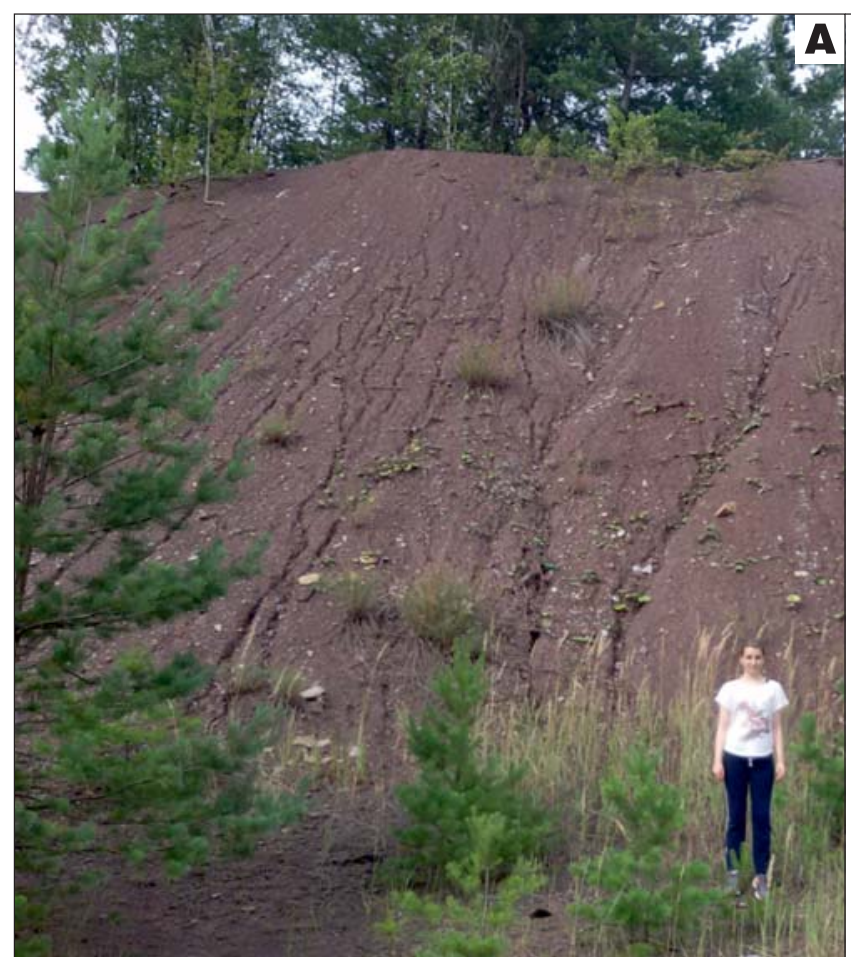

\section{DYSKUSJA}

W pierwszym zbiorze warp, wytypowanym w północno-wschodniej części badanego obszaru, wokół dawnych miejsc eksploatacji występują chaotycznie rozmieszczone małe usypiska - można je wiązać z górnictwem średniowiecznym. Doły górnicze pochodzące z tego okresu były drążone prostymi narzędziami do głębokości kilku metrów i przeważnie miały powierzchnię ok. $5 \mathrm{~m}^{2}$ (Chłopek, 2017). Na dawne pochodzenie tych wyrobisk i usypisk może wskazywać także ich lokalizacja - znajdują się one w pobliżu wychodni horyzontu rudonośnego (Mizerja, 1947). Takie umiejscowienie wyrobisk sprzyjało wydobyciu rudy $\mathrm{w}$ średniowieczu, kiedy pozyskiwano ją z najłatwiej dostępnej części horyzontu rudnego, zalegającej tuż pod powierzchnią terenu (Chłopek, 2017). Na obszarze tego zbioru form mogą również występować różnowiekowe rowy i szyby poszukiwawcze (por. Rutkiewicz, 2017).

Wyraźniejsze i większe wloty szybów i warpy o nieregularnym rozmieszczeniu (zbiory 2 i 3) można wiązać z nowożytnym systemem eksploatacji złoża, w ramach którego wykonywano wyrobiska pionowe (dukle), umożliwiające penetrację górotworu do głębokości ok. 10-12 m, a wraz z rozwojem metody szybikowej - do ponad $30 \mathrm{~m}$ (Chłopek, 2017).

Regularne rozmieszczenie warp w zachodniej części obszaru (zbiór 4), co ok. 40-50 m, świadczy o wieloszybikowym systemie eksploatacji złoża (Bednarski, 1955), powszechnie stosowanym już w XVII w. (Król, Urban, 2003). Jednak większe rozmiary warp niż w zbiorach 1-3 (tab. 1, 2) najpewniej oznaczają głębsze szyby (por. Rutkiewicz, 2017), a wobec tego wydajniejszą eksploatację, wynikająca zapewne z zastosowania nowocześniejszej
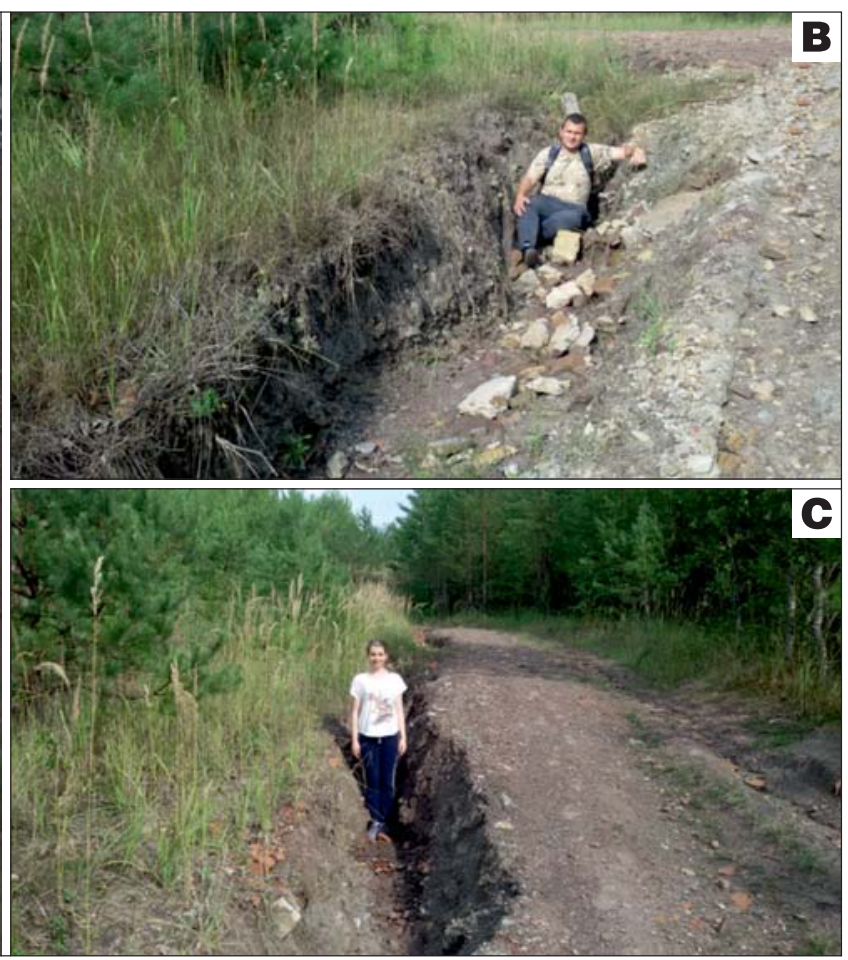

Ryc. 7. Skutki erozji wodnej (bruzdy i żłobiny): A - na stoku zwałowiska; B i C - przy drodze prowadzącej do zwałowiska. Fot. P. Kusztal i A. Andrzejczyk, 2019

Fig. 7. Effects of the water erosion (rills): $\mathbf{A}$ - on the slope of the mining heap; $\mathbf{B}$ and $\mathbf{C}$ - on the road leading to the mining heap. Photos by P. Kusztal and A. Andrzejczyk, 2019 

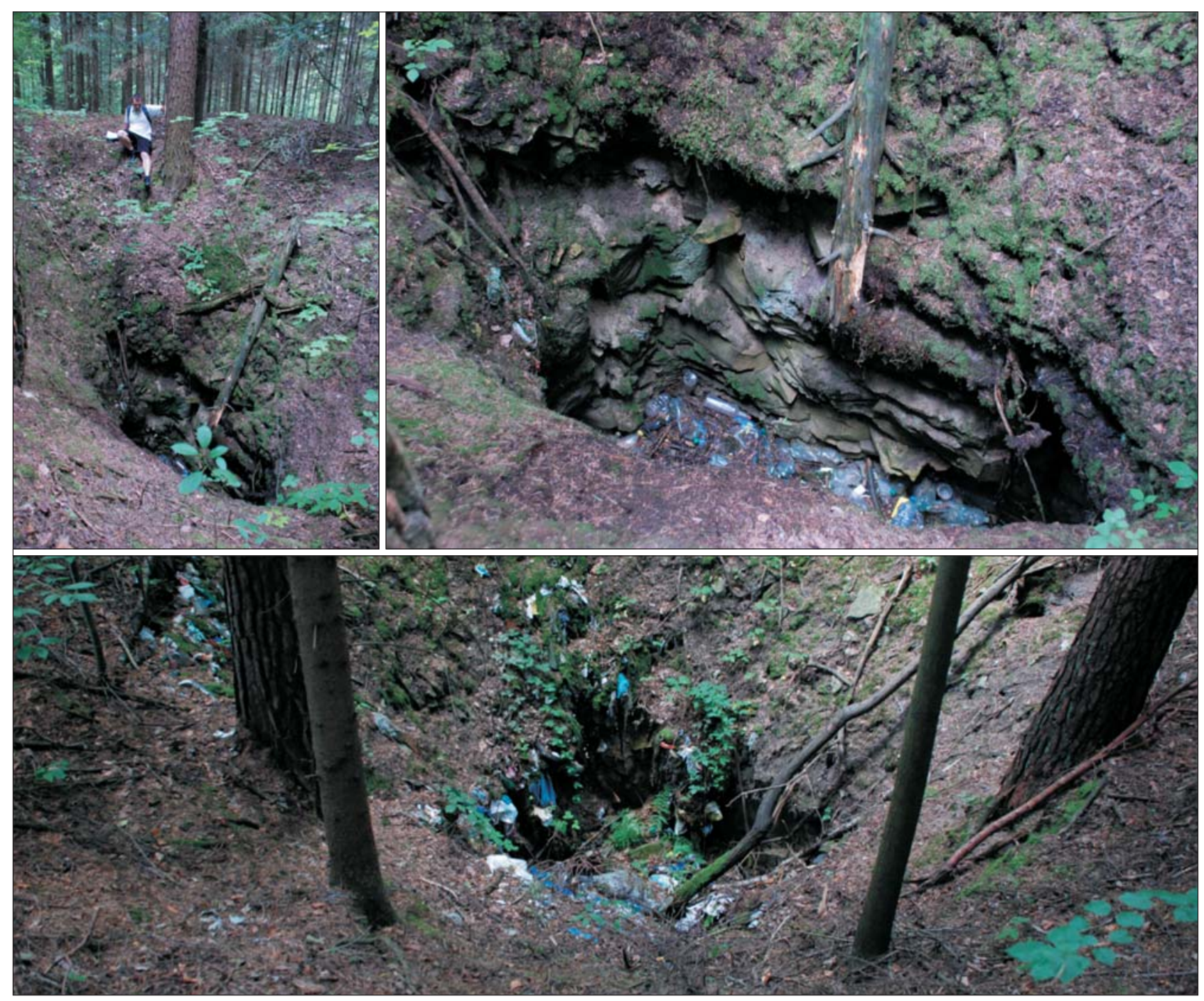

Ryc. 8. Szyby kopalniane zaczopowane osadami, materią organiczną i odpadami. Fot. G. Pabian, 2019

Fig. 8. Mining shafts plugged by sediments, organic matter and wastes. Photos by G. Pabian, 2019

technologii. Ponadto największa wyrazistość usypisk wyróżnionych w czwartym zbiorze pozwala przypuszczać, że krócej podlegały one denudacji, co oznacza, że są młodsze od form znajdujących się w zbiorach 1-3. Zwałowisko (zbiór piąty) jest efektem działalności XX-wiecznej kopalni Edward o czterech szybach głębokości 40-80 m (Chłopek, 2017) i świadczy o znacznej intensyfikacji wydobycia rudy na tym terenie w II połowie XX w.

Na podstawie analizy materiałów źródłowych (Mizerja, 1947; Bednarski, 1955; Krajewski, 1955; Król, Urban, 2003; Kuliński, 2014; Rutkiewicz, Gawior, 2015; Chłopek, 2017; Nowak, 2017; Rutkiewicz, 2017) wywnioskowano, że parametry morfometryczne i rozmieszczenie warp są zależne od czasu ich usypania, a według Rutkiewicza i Gawiora (2015), którzy badali pole górnicze na Wyżynie Śląskiej, im większy mają one rozmiar i mniejszą koncentrację (ryc. 5, tab. 2), tym są młodsze. Dodatkowo, subiektywnie wskazana i potwierdzona przez sztuczną inteligencję odrębność zbiorów 1, 4 i 5 (ryc. 6), wynikająca ze zróżnicowania wartości trzech zmiennych, umacnia wiarygodność postawionej hipotezy, że obszary wytyczone na badanym polu górniczym (ryc. 5) były eksploatowane w innym czasie.

Lokalizacja najmniejszych form poeksploatacyjnych o dużej koncentracji (ryc. 5) jest w przybliżeniu zgodna z przebiegiem wychodni pierwszego horyzontu rudnego (ryc. 2). Linia tej wychodni z jednej strony odwzorowuje budowę geologiczną, ponieważ horyzont rudny odsłania się na skrzydłach synkliny, a z drugiej nawiązuje do rzeźby terenu, gdyż linia ta przebiega po skłonie wierzchowiny, z trzech stron (N, E, S) otaczającym pole górnicze (Mizerja, 1947; Krajewski, 1955). Brak podobnych warp w zachodniej części pola górniczego może być związany z zapadaniem utworów rudonośnych w tym kierunku (por. Mizerja, 1947). Zapadanie warstw na zachód obrazują także przekroje geologiczne wschodniej części obszaru badań, wykonane w przybliżeniu wzdłuż osi synkliny (Mizerja, 1947; Krajewski, 1955).

Rzeźba badanego terenu jest przekształcana przez erozję wodną i ruchy masowe (ryc. 7, 8). Dynamika tych procesów jest znacznie większa na obszarze pola górniczego niż w jego otoczeniu, gdzie nie prowadzono działalności wydobywczej.

\section{PODSUMOWANIE I WNIOSKI}

1) Wielowiekowa działalność górnicza na wierzchowinie Osicowej Góry doprowadziła do powstania poeksploatacyjnej rzeźby terenu. Tego typu zmiany środowiskowe 
są charakterystyczne dla antropocenu (Brown i in., 2017). $\mathrm{Na}$ badanym obszarze rozpoczęły się one przed tzw. wielkim przyspieszeniem, tj. okresem dynamicznie narastającej antropopresji, trwającym od połowy XX w. (Waters i in., 2016).

2) Głównym powodem zróżnicowania poeksploatacyjnych form rzeźby badanego terenu były zmiany technologii wydobycia rudy. Ich rozmiary i rozmieszczenie (lokalizacja, układ i koncentracja) zależą więc od czasu oraz sposobu eksploatacji złoża. Mają również związek z budową geologiczną i morfologią terenu.

3) Formy pogórnicze są intensywnie przekształcane przez współczesne procesy morfodynamiczne.

Dziękujemy dr. hab. inż. Janowi Urbanowi (IOP PAN, Kraków) za rady $\mathrm{i}$ inspiracje, Recenzentom za cenne uwagi, dr. inż. Zbigniewowi Złonkiewiczowi za konsultacje dotyczące zagadnień geologicznych (PIG, Kielce), a mgr Katarzynie Pabian i mgr inż. Aleksandrze Andrzejczyk za pomoc i dyskusje w terenie.

\section{LITERATURA}

BEDNARSKI M. 1955 - Górnictwo ogólne, część II. PWN, Łódź-Kraków.

BORZECCKI R., MAREK A. 2016 - Pozostałości górnictwa rud uranu w Masywie Śnieżnika. Hereditas Minariorum, 3: 109-133.

BROWN A.G., TOOTH S., BULLARD J.E., THOMAS D.S.G., CHIVERRELL R.C., PLATER A.J., MURTON J., THORNDYCRAFT V.R., TAROLLI P., ROSE J., WAINWRIGHT J., DOWNS P., AALTO R. 2017 - The geomorphology of the Anthropocene: emergence, status and implications. Earth Surf. Proc. Landforms, 42: 71-90.

CHŁOPEK M. 2017 - Dolina Czarnej: Zapomniane Dziedzictwo. Stow. W Dolinie Czarnej. Zabytk. Zak. Hut. w Maleńcu, Maleniec. FIJAŁKOWSKA-MADER A., ZŁONKIEWICZ Z. 2019 - Stanowiska 2.3-2.6. Litostratygrafia dolnego triasu oraz dolnej jury. [W:] Urban J. (red.), Rzeźba strukturalna Gór Świętokrzyskich i Ponidzia - stan badań i perspektywy badawcze. Streszczenia referatów i posterów, przewodnik sesji terenowych VII Warszt. Geomor. Strukt., 26-28 września 2019 r. Wyd. UJK, Kielce: 86-89.

FILONOWICZ P. 1981 - Mapa geologiczna Polski. B - mapa bez utworów czwartorzędowych w skali 1: 200 000. Ark. Kielce. Inst. Geol., Wyd. Geol., Warszawa.

GILEWSKA S. 1972 - Wyżyna Śląsko-Małopolska. [W:] Klimaszewski M. (red.), Geomorfologia Polski, tom 1. PWN, Warszawa: 305-326.

https://mapy.geoportal.gov.pl

KALICKI T., PRZEPIÓRA P., FRĄCZEK M., KUSZTAL P. 2018 - The geoarchaeological potential of the Suchedniów-Oblegorek Landscape Park and its buffer zone (Świętokrzyskie Voivodeship, south-eastern Poland). [W:] Karczewska M., Karczewski M., Pluskowski A., Sobieraj J. (red.), The Archaeology of Woodlands. Book of abstracts of Inter. Conf., 19-21 april 2018, Białystok: 64.

KAPTUR K. 2014 - Podziemne górnictwo rud żelaza w rejonie Ostrowca Świętokrzyskiego i inwentaryzacja reliktów dawnych robót górniczych. Hereditas Minariorum, 1: 131-144.

KASZOWSKA O. 2007 - Wpływ podziemnej eksploatacji górniczej na powierzchnię terenu. Probl. Ekol., 11 (1): 52-57.

KOHONEN T. 1997 - Self-Organizing Maps. Springer, Berlin-Heidelberg-New York.

KRAJEWSKI R. 1955 - Szczegółowa Mapa Geologiczna Polski w skali 1:50 000. Ark. Odrowąż. Wyd. Geol. (druk w 1962).

KRÓL P., URBAN J. 2003 - Kopalnie w Miedzianej Górze i w Ławęcznej oraz ochrona ich pozostałości. Rocz. Św., Ser. B - Nauki Przyrodnicze, 29: 1-44.

KUBICKI R., SALETRA W. 2013 - Hutnictwo i górnictwo w regionie świętokrzyskim - do Księstwa Warszawskiego. Stud. i Mater. Misc. Oecon., 17 (2): 29-40.

KULIŃSKI I. 2014 - O górnikach rud żelaza, kuźnicach i kowalichach w Staropolskim Okręgu Przemysłowym. Muz. im. Orła Białego w Skarżysku-Kamiennej, Skarżysko-Kamienna.

MACIEJAK K., KOWALSKI A., MACIEJAK M. 2017 - Górnictwo miedzi w rejonie Kondratowa (Pogórze Kaczawskie). Hereditas Minariorum, 4: 65-80.
MIZERJA W. 1947 - Przyczynki do znajomości budowy geologicznej kopalni Stanisław pod Staporkowem. Biul. Państw. Inst. Geol., 39: 29-59. MŁODAWSKI M. 2017 - Górnicze dziedzictwo gminy Stąporków. [W:] Nowak S. (red.), Almanach Świętokrzyski, Stapporków i okolice z historia industrialna $\mathrm{w}$ tle, tom 2. Oficyna Wyd. Edward Mitek, Warszawa-Bydgoszcz-Kielce: 135-144.

MYGA-PIĄTEK U. 2012 - Krajobrazy kulturowe. Aspekty ewolucyjne i typologiczne. Wyd. UŚ

NOWAK E. 2004 - Metody klasyfikacji w badaniach geograficznych (analiza porównawcza). Wyd. Nauk. Bogucki, Kielce-Poznań

NOWAK S. 2017 - Kopalnictwo rud żelaza okolic Stąporkowa (od średniowiecza do drugiej połowy XX wieku). [W:] Nowak S. (red.), Almanach Świetokrzyski, Staporków i okolice z historia industrialna w tle, tom 2. Oficyna Wyd. Edward Mitek, Warszawa-Bydgoszcz-Kielce: 229-253.

PABIAN G., KUSZTAL P. 2019 - Zmiany rzeźby na terenie Osicowej Góry w pobliżu Stąporkowa (NW obrzeżenie Gór Świętokrzyskich) spowodowane działalnością górniczą. [W:] Urban J. (red.), Rzeźba strukturalna Gór Świętokrzyskich i Ponidzia - stan badań i perspektywy badawcze. VII Warszt. Geomor. Strukt., 26-28 września 2019 r., Streszczenia referatów i posterów, Przewodnik sesji terenowych. Wyd. UJK, Kielce: $47-48$.

PABIAN G., KUSZTAL P., KALICKI T., PRZEPIÓRA P. 2019 - Changes in relief caused by historical mining activities (case study from the area of Osicowa Góra hill in central Poland). [W:] Kleprlikova L., Plichta A., Turek T. (red.), Sbornik abstrakt -25 . Kvarter. Book of Abstracts of $25^{\text {th }}$ Quaternary Conference, 29 november 2019. Wyd. Uniw. Masaryka, Brno: 53.

PIEŃKOWSKI G. 2004 - The epicontinental Lower Jurassic of Poland. Pol. Geol. Inst. Sp. Papers, 12: 1-154.

PRZEPIÓRA P., HOUBRECHTS G., KALICKI T., PEETERS A., PABIAN G., KUSZTAL P., NOWAK E., RUTKIEWICZ P. 2019 Post-mining relief and its present-day changes in the European Hercinian Mountains - cases study from Ardennes and Holy Cross Mountains. [W:] Kleprlikova L., Plichta A., Turek T. (red.), Sbornik abstrakt-25. Kvarter. Book of Abstracts of $25^{\text {th }}$ Quaternary Conference, 29 November 2019. Wyd. Uniw. Masaryka, Brno: 55.

RADWANEK-BĄK B. 2001 - Trwałość i dynamika przekształceń wywołanych eksploatacją odkrywkową kopalin. Prz. Geol., 49 (3): 220-224.

RUTKIEWICZ P., GAWIOR D. 2015 - Górnictwo kruszcowe jako czynnik kształtujący krajobraz w rezerwacie Segiet (Wyżyna Śląska) na podstawie danych lidarowych. [W:] Machowski R., Rzętała M.A. (red.), Z badań nad wpływem antropopresji na środowisko, tom 16. Wyd. Wydz. Nauk o Ziemi UŚ, Sosnowiec: 80-86.

RUTKIEWICZ P. 2017 - Wykorzystanie danych LIDAR w badaniach zmiany rzeźby terenu, wynikających z działalności dawnych kopalń rud żelaza. [W:] Machowski R. (red.), Z badań nad wpływem antropopresji na środowisko, tom 18. Wyd. Wydz. Nauk o Ziemi US, Sosnowiec: 40-47. SOJA R. 2003 - Mapa Hydrograficzna w skali 1:50 000. Ark. Stąporków. GUGiK, Warszawa.

SOLON J., BORZYSZKOWSKI J., BIDŁASIK M., RICHLING A., BADORA K., BALON J., BRZEZIŃSKA-WÓJCIK T., CHABUDZIŃSKI Ł., DOBROWOLSKI R., GRZEGORCZYK I., JODŁOWSKI M., KISTOWSKI M., KOT R., KRĄŻ P., LECHNIO J., MACIAS A., MAJCHROWSKA A., MALINOWSKA E., MIGOŃ P., MYGA-PIACTEK U., NITA J., PAPIŃSKA E., RODZIK J., STRZYŻ M., TERPIŁOWSKI S., ZIAJA W. 2018 - Physico-geographical mesoregions of Poland: Verification and adjustment of boundaries on the basis of contemporary spatial data. Geographia Pol., 91 (2): 143-170.

SZTAMPKE M. 2014 - Laserowi Odkrywcy. Nieinwazyjne badanie i dokumentowanie obiektów archeologicznych i historycznych województwa świętokrzyskiego. Fundacja Centrum GeoHistorii, Stare Babice.

WATERS C.N., ZALASIEWICZ J., SUMMERHAYES C., BARNOSKY A.D., POIRIER C., GAŁUSZKA A., CEARRETA A., EDGEWORTH M., ELLIS E.C., ELLIS M., JEANDEL C., LEINFELDER R., MCNEILL J.R., RICHTER D., STEFFEN W., SYVITSKI J., VIDAS D., WAGREICH M., WILLIAMS M., ZHISHENG A., GRINEVALD J., ODADA E., ORESKES N., WOLFE A.P. 2016 - The Anthropocene is functionally and stratigraphically distinct from the Holocene. Science, 351 (6269): aad2622. WERENS A. 2005 - Czarniecka Góra. Historia uzdrowiska. Wyd. Biblioteki Publicznej Miasta i Gminy Końskie - ARSLIBRIS, Końskie. WIELOMSKA W. 2000 - Mapa topograficzna w skali 1: 50 000. Ark. Końskie, wyd. I (akt. topogr. - 1974 r.), OPGK-Rzeszów S.A.

ZŁONKIEWICZ Z. 2019 - Objaśnienia do Szczegółowej Mapy Geologicznej Polski w skali 1:50 000. Ark. Odrowąż. Państw. Inst. Geol., Min. Środ., Warszawa. 